\title{
The effects of chemotherapy on antibody levels in lepromatous patients
}

\author{
J T DOUGLAS, ${ }^{*}$ L M STEVEN,${ }^{*}$ T FAJARDO, $\dagger$ \\ R V CELLONA, $\dagger$ M G MADARANG, $\dagger$ \\ R M ABALOS $\dagger \&$ G J STEENBERGEN $\dagger$ \\ *University of Hawaii, Honolulu, HI; $\nmid$ Leonard Wood Memorial \\ Center for Leprosy Research, Cebu, Phillippines
}

Accepted for publication 29 September 1987

\begin{abstract}
Summary We compare whole cell ELISA antigens (Mycobacterium leprae) and two specific antigens: PG-I, phenolic glycolipid I of $M$. leprae and M-BGG, a synthetic antigen representing the terminal sugar of PG-I for their effectiveness in detecting antibody during chemotherapy. By the end of the 1st year of treatment, antibody levels to M-BGG had declined by $42 \%$ of the initial ELISA values, by the end of the 2 nd year by $61 \%$ and at the end of 3 years by $68 \%$. Declines of similar magnitude were seen with the other antigens. We examined these sera by RID for changes in levels of IgG, IgM and IgA antibodies. The levels of IgG remained abnormally high throughout the 3 years of antimicrobial therapy. The serum levels of IgM and IgA antibodies remained at the upper limits of normal range. The decline seen with antibody to $M$. leprae antigens was not reflected by a similar decline of serum immunoglobulin levels. Thus, application of ELISA monitoring during the course of treatment may be valuable in measuring the effectiveness of chemotherapy.
\end{abstract}

\section{Introduction}

With the emergence of ever increasing numbers of dapsone resistant $M$. leprae infections, the importance of monitoring chemotherapy has been established. Chemotherapy has been further compromised by poor compliance of patients (especially by light-skinned patients treated with clofazimine), ${ }^{1}$ the necessity of daily treatment, lack of drug delivery and by toxic side-effects. Newer chemotherapeutic agents such as rifampicin may alleviate some of these problems, but careful monitoring is still critically important. A sensitive assay which can detect quantitatively anti- $M$. leprae antibodies could reflect the bacterial load and hence the emergence of resistant mutants and/ or lack of adherence to a drug regimen. Changes in patients' sera may be early indicators of changes in disease status. To that end, we have been examining leprosy patients' sera by ELISA (enzymelinked immunosorbent assay) with both natural and semisynthetic antigens for their efficacy in detecting antibody during treatment of lepromatous patients. Melsom et al. ${ }^{2}$ using a solid phase radioimmunoassay showed gradual changes in $\operatorname{IgG}$ and $\operatorname{IgA}$ antibody reactivity against antigen 7 and a smaller decline in specific IgM activity during the initial 2-4 years of therapy in lepromatous 
patients. Similar declines in antibody levels with continuing chemotherapy in dapsone-responsive patients have been noted by others. ${ }^{3}$ We compare a whole cell ELISA antigen (M. leprae) and 2 specific ELISA antigens (PG-I, phenolic glycolipid I of $M$. leprae and M-BGG, a synthetic antigen representing the terminal sugar of PG-I which is conjugated to bovine gamma globulin) for their effectiveness in monitoring chemotherapy of lepromatous patients from the Leonard Wood Memorial Leprosy Research Center, Cebu, PI. As noted by others, ${ }^{4}$ the serodiagnosis of leprosy has been complicated by the extensive cross-reactions between mycobacterial species. The effects of chemotherapy on antibody levels in sera from 41 lepromatous individuals treated with dapsone over a 5-year period was examined by ELISA. We also examined these patients' sera immunoglobulin levels by radial immunodiffusion for quantitative changes in $\mathrm{IgG}$, IgM and IgA antibodies.

\section{Methods}

ELISA

The ELISA used in this report was a n indirect assay with a $0.05 \mathrm{ml}$ suspension of antigen dried onto ' $U$ ' bottom microtiter plates. Antigen coated wells were blocked to prevent nonspecific binding by adding $0.075 \mathrm{ml}$ of $5.0 \%$ goat serum in phosphate buffered saline, $\mathrm{pH} 7.2$ (PBS) and incubating overnight at $4^{\circ} \mathrm{C}$. The remainder of the assay was carried out as previously described..$^{5,6}$

\section{ANTIGEN PREPARATION}

The Immulon II plates (Dynatech Laboratories, Alexandria, VA, 22314) were coated with antigen in a volatile buffer. The whole cells, $M$. leprae, used as ELISA antigen, were suspended in a volatile coating buffer at a concentration of $0 \cdot 04$ absorbance units. The volatile coating buffer used was $0 \cdot 01$ M, $\mathrm{pH} 8.2$ ammonium acetate carbonate. The purified antigen, phenolic glycolipid I (PG-I) of $M$. leprae was prepared by sonicating the PG-I $(100 \mu \mathrm{g} / \mathrm{ml})$ in the volatile buffer for $30 \mathrm{~s}$ three times with a $3 \mathrm{~mm}$ probe. ${ }^{7,8}$ This suspension was then diluted to a concentration of $4.0 \mu \mathrm{g} / \mathrm{ml}$ with the same buffer. The third antigen was a neoglycoprotein, which contained the monosaccharide, 3,6-di- $O$ methyl glucopyranose, linked to bovine gamma globulin (M-BGG) and represented the terminal sugar of the phenolic glycolipid-I antigen of M. leprae. ${ }^{9}$ The M-BGG was diluted from the concentrated solution to $1: 4000(0 \cdot 78 \mu \mathrm{g} / \mathrm{ml})$ or $1: 4500(0 \cdot 69 \mu \mathrm{g} / \mathrm{ml})$ and mixed thoroughly. Each of the 3 antigens was coated on microtiter plates by adding $0.05 \mathrm{ml}$ of antigen suspension to each well. The plates were then incubated overnight at $37^{\circ} \mathrm{C}$ to dry the antigen onto the plate. The antigen coated plates can then be stored for several months at room temperature. M. leprae, PG-I and MBGG were provided under NIH contract by Dr P Brennan, Colorado State University.

\section{SERA}

In Cebu, sera were collected and stored every 4 weeks starting on admission and up to 6 months. Subsequently, blood withdrawal was performed every 6 months up to the 24 th month and then once a year up to the end of the study on the 5th year.

\section{CASE DATA}

Sera from this study was collected from patients who participated in the Joint Chemotherapy Trial (JCT) conducted by Leonard Wood Memorial Center for Leprosy Research in Cebu, Philippines in collaboration with Sasakawa Memorial Health Foundation Tokyo, Japan and the Department of Health, Philippines. Sera of patients from 2 chemotherapeutic protocols (1a and 1c) of the joint chemotherapy study were used. Patients in group 1 a received dapsone $100 \mathrm{mg} /$ day, 6 times per week for 5 years and rifampicin $1.2 \mathrm{~g}$ once on admission. Patients in group $1 \mathrm{c}$ received dapsone $100 \mathrm{mg} /$ 
day, 6 times per week for 5 years, and clofazimine $100 \mathrm{mg}$ three times per week for the first 24 weeks and rifampicin $1.2 \mathrm{~g}$ once on admission. The patients were newly diagnosed previously untreated lepromatous cases free of any serious intercurrent disease and screened by chest X-ray to be free of tuberculosis and of ENL on admission to the trial, all were clinically lepromatous and histologically LL with mean bacterial index of $4 \cdot 59 \pm 0 \cdot 4$. A total of 38 patients were admitted over a 3-year period, sequentially and randomly allocated to either $1 \mathrm{a}$ or $1 \mathrm{c}$. There were 17 males with ages 12-56 years old (average age 25.47) on admission to group la and 17 males $12-55$ years old (average age 22.41) and 3 females 16-22 years old (average age 18.33) for group 1c. Eight patients in 1a and 8 patients in $1 \mathrm{c}$ dropped out during the course of the drug trial. Preliminary evaluation did not show any significant difference between the 2 therapy regimens ( $1 \mathrm{a} v s \mathrm{lc}$ ) in terms of clinical improvement, bacteriologic reduction and occurrence of reaction states. Because of the low number of patients in each treatment group, the varying length of patient participation within the trial and lack of observable differences in patient recovery between the therapy regimens, the data from the 2 groups were combined unless otherwise stated.

\section{RADIAL IMMUNODIFFUSION}

The radial immunodiffusion procedure was used for the quantitation of $\operatorname{IgG}, \operatorname{IgM}$ and $\operatorname{IgA} .{ }^{10}$ The prepared kits were from Helena Laboratories (Beaumont, Texas). The immunoglobulin reference standards were standardized against the World Health Organization Reference Standard.

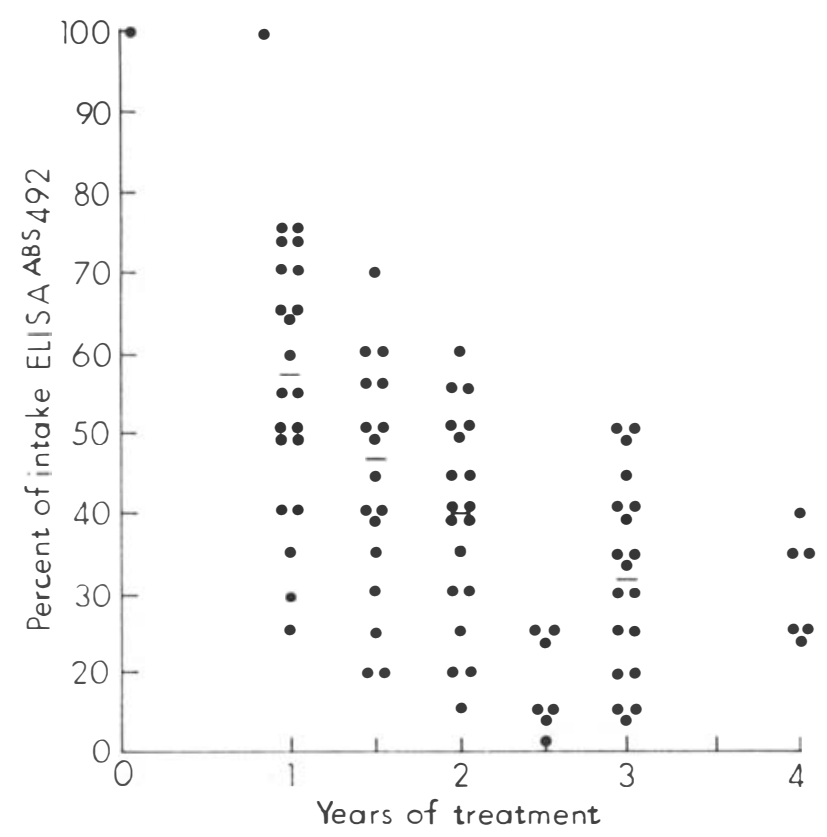

Figure 1. This figure represents the pooled data from patients treated by both therapeutic protocols (1a \& $1 \mathrm{c})$. Each dot represents the average of paired ELISA values for each serum. The ELISA values have been adjusted to represent a percentage of the patients ELISA value at the start of treatment. The bars indicate mean values. The neoglycoprotein antigen used contained the monosaccharide, 3,6-di- $O$-methyl glyucopyranose, linked to bovine gamma globulin (M-BGG), representing the terminal sugar of the phenolic glycolipid-I antigen of $M$. leprae. The 1 st year of chemotherapy resulted in a $43 \%$ decline in ELISA values. As treatment continued an additional decline in median ELISA values was observed of $18 \%$ in the 2 nd year and $7 \%$ in the 3 rd year. Thus resulting in an over all decline of $68 \%$ from initial values af ter 3 years of treatment. 


\section{Results}

EFFECT OF THERAPY ON SPECIFIC ANTIBODY LEVELS IN LEPROMATOUS PATIENTS

Figure 1 shows the decline in ELISA values of M-BGG over 4 years of chemotherapy of lepromatous patients. By the end of the 1st year of therapy, antibody levels from 22 patients to the synthetic antigen M-BGG had declined to $58 \%(+/-8 \cdot 17 \%$ with $95 \%$ confidence limit using Student's t distribution $)^{11}$ of the initial ELISA values. By the end of the 2nd year, the mean ELISA values from 19 patients had dropped to $39 \%(+/-6 \cdot 3 \%$ with $95 \%$ confidence limit $)$ of the initial values and at the end of 3 years, the mean for 18 patients had reached $31 \cdot 8 \%(+/-6 \cdot 1 \%$ with $95 \%$ confidence limit) of the starting values. This is a mean decline of $68 \%$ over a 3 -year period after the initiation of therapy.

Tables 1 and 2 present ELISA data demonstrating individual patients sera reactivity to the 3 antigens over the course of treatment with the 2 protocols ( 1 a \& 1c). Table 1 shows the decline of antibody titer to the synthetic antigen M-BGG, the semisynthetic antigen PG-I and whole cell antigen from $M$. leprae with treatment. In the 4 patient examples, there were significant declines demonstrated with all 3 antigen preparations over a 3-year period. There were also declines in the bacterial indices. For example, patient number 019 had an initial M-BGG OD of 0.70 and after 1 year of chemotherapy this value had dropped to $0 \cdot 28$; after 2 years to $0 \cdot 17$ and after 3 years to $0 \cdot 10$.

Table 1. Use of M-BGG, PG-I and $M$. leprae in serial testing of sera from treated lepromatous patients*

\begin{tabular}{|c|c|c|c|c|c|}
\hline \multirow[b]{2}{*}{$\begin{array}{l}\text { Patient } \\
\text { No. }\end{array}$} & \multirow[b]{2}{*}{$\begin{array}{c}\text { Date of } \\
\text { bleedings }\end{array}$} & \multicolumn{4}{|c|}{ Mean A492nm } \\
\hline & & M-BGG & M. leprae & PGI & $\begin{array}{c}\text { Bacterial } \\
\text { Index }\end{array}$ \\
\hline \multirow[t]{5}{*}{035} & $13-02-81$ & 0.86 & $0 \cdot 82$ & $0 \cdot 78$ & $4 \cdot 3$ \\
\hline & $22-02-82$ & 0.65 & 0.61 & $0 \cdot 71$ & $4 \cdot 5$ \\
\hline & $16-08-82$ & $0 \cdot 51$ & 0.43 & 0.53 & $4 \cdot 2$ \\
\hline & $25-02-83$ & 0.43 & $0 \cdot 30$ & 0.42 & $4 \cdot 5$ \\
\hline & $25-02-84$ & $0 \cdot 36$ & $0 \cdot 36$ & 0.44 & $3 \cdot 7$ \\
\hline \multirow[t]{5}{*}{045} & $25-06-81$ & $0 \cdot 25$ & 0.79 & $0 \cdot 37$ & $3 \cdot 8$ \\
\hline & $07-07-82$ & $0 \cdot 16$ & 0.48 & $0 \cdot 14$ & $4 \cdot 0$ \\
\hline & $10-01-83$ & $0 \cdot 14$ & 0.41 & $0 \cdot 13$ & $4 \cdot 0$ \\
\hline & $18-07-83$ & $0 \cdot 10$ & 0.42 & $0 \cdot 12$ & $3 \cdot 7$ \\
\hline & $27-06-84$ & 0.05 & $0 \cdot 30$ & $0 \cdot 10$ & $3 \cdot 0$ \\
\hline \multirow[t]{3}{*}{007} & $09-01-80$ & $1 \cdot 10$ & $1 \cdot 10$ & $1 \cdot 10$ & $4 \cdot 0$ \\
\hline & $10-02-81$ & $0 \cdot 54$ & 0.46 & $0 \cdot 62$ & $3 \cdot 0$ \\
\hline & $08-02-83$ & $0 \cdot 19$ & 0.42 & $0 \cdot 26$ & 0 \\
\hline \multirow[t]{6}{*}{019} & $26-11-80$ & $0 \cdot 70$ & $1 \cdot 54$ & $0 \cdot 87$ & $4 \cdot 7$ \\
\hline & $25-05-81$ & 0.67 & $1 \cdot 50$ & $0 \cdot 73$ & $2 \cdot 8$ \\
\hline & $01-12-81$ & $0 \cdot 28$ & $1 \cdot 26$ & $0 \cdot 40$ & $3 \cdot 3$ \\
\hline & $27-05-82$ & $0 \cdot 17$ & $0 \cdot 87$ & $0 \cdot 20$ & $2 \cdot 0$ \\
\hline & $23-05-83$ & $0 \cdot 10$ & $0 \cdot 75$ & $0 \cdot 19$ & $0 \cdot 8$ \\
\hline & $22-05-84$ & $0 \cdot 10$ & 0.73 & $0 \cdot 16$ & $0 \cdot 4$ \\
\hline
\end{tabular}

* Chemotherapy was conducted at the Leonard Wood Foundation facility in Cebu, Philippines in conjunction with the Sasakawa Memorial Health Foundation. Chemotherapeutic protocol 'la': dapsone, $100 \mathrm{mg}$ six times per week for 5 years; rifampicin, $1 \cdot 2 \mathrm{~g}$ once on admission. 
Table 2. Use of M-BGG, PG-I and $M$. leprae in serial testing of sera from treated lepromatous patients*

\begin{tabular}{|c|c|c|c|c|c|}
\hline \multirow[b]{2}{*}{$\begin{array}{l}\text { Patient } \\
\text { No. }\end{array}$} & \multirow[b]{2}{*}{$\begin{array}{c}\text { Date of } \\
\text { bleedings }\end{array}$} & \multicolumn{4}{|c|}{ Mean A492nm } \\
\hline & & M-BGG & M. leprae & PGI & $\begin{array}{c}\text { Bacterial } \\
\text { Index }\end{array}$ \\
\hline \multirow[t]{5}{*}{022} & $04-11-80$ & $1 \cdot 01$ & 0.77 & $1 \cdot 20$ & $4 \cdot 5$ \\
\hline & $04-02-81$ & 0.91 & 0.56 & 1.08 & $3 \cdot 2$ \\
\hline & $02-08-82$ & $0 \cdot 29$ & 0.50 & 0.47 & $3 \cdot 7$ \\
\hline & $02-08-83$ & $0 \cdot 16$ & $0 \cdot 21$ & $0 \cdot 23$ & $2 \cdot 2$ \\
\hline & $02-08-84$ & $0 \cdot 14$ & $0 \cdot 28$ & $0 \cdot 21$ & $2 \cdot 0$ \\
\hline \multirow[t]{6}{*}{056} & $22-01-82$ & $0 \cdot 60$ & $1 \cdot 43$ & $0 \cdot 75$ & $5 \cdot 0$ \\
\hline & $02-08-82$ & $0 \cdot 30$ & $1 \cdot 18$ & $0 \cdot 55$ & $4 \cdot 0$ \\
\hline & $04-02-83$ & $0 \cdot 19$ & 0.55 & $0 \cdot 25$ & $4 \cdot 3$ \\
\hline & $01-08-83$ & $0 \cdot 11$ & 0.42 & $0 \cdot 30$ & $3 \cdot 7$ \\
\hline & $07-02-84$ & $0 \cdot 14$ & 0.44 & $0 \cdot 34$ & $3 \cdot 5$ \\
\hline & $02-08-84$ & $0 \cdot 10$ & $0 \cdot 27$ & $0 \cdot 18$ & $2 \cdot 5$ \\
\hline \multirow[t]{5}{*}{055} & $22-01-82$ & $0 \cdot 77$ & $1 \cdot 32$ & $0 \cdot 81$ & $4 \cdot 2$ \\
\hline & $02-08-82$ & 0.43 & $1 \cdot 19$ & $0 \cdot 68$ & $4 \cdot 3$ \\
\hline & $04-02-83$ & $0 \cdot 28$ & $1 \cdot 07$ & $0 \cdot 46$ & $3 \cdot 5$ \\
\hline & $01-08-83$ & $0 \cdot 19$ & 0.87 & 0.42 & $3 \cdot 2$ \\
\hline & $07-02-84$ & $0 \cdot 30$ & 1.03 & $0 \cdot 59$ & $2 \cdot 7$ \\
\hline \multirow[t]{4}{*}{063} & $23-04-82$ & 0.91 & $1 \cdot 39$ & $1 \cdot 22$ & $4 \cdot 5$ \\
\hline & $03-11-82$ & 0.54 & $0 \cdot 70$ & $1 \cdot 14$ & $3 \cdot 0$ \\
\hline & $03-05-83$ & $0 \cdot 15$ & 0.46 & $0 \cdot 66$ & $3 \cdot 2$ \\
\hline & $02-05-84$ & 0.09 & $0 \cdot 34$ & $0 \cdot 42$ & $1 \cdot 2$ \\
\hline
\end{tabular}

* Chemotherapy was conducted at the Leonard Wood Foundation facility in Cebu, Philippines, in conjunction with the Sasakawa Memorial Health Foundation. Chemotherapeutic protocol ' $1 \mathrm{c}$ ': dapsone, $100 \mathrm{mg}$ six times per week for 5 years; clof azimine, $100 \mathrm{mg}$ three times per week for 24 weeks; rifampicin, $1 \cdot 2 \mathrm{~g}$ once on admission.

The values for $M$. leprae were: $1 \cdot 54,1 \cdot 26,0 \cdot 87$ and $0 \cdot 75$. For PG-I the values declined as follows: $0 \cdot 87,0 \cdot 40,0 \cdot 20$, and $0 \cdot 19$. The bacterial index also showed decline: $4 \cdot 7,3 \cdot 3,2 \cdot 0,0 \cdot 8$. The decline in ELISA values was most rapid with the M-BGG and PG-I antigens.

Table 2 shows the decline in titer with the same antigens af ter similar chemotherapy but with the addition of clofazimine, $100 \mathrm{mg}$ three times per week for 24 weeks. Again there were significant declines with the 3 antigens and in the bacterial indices. A representative patient, number 022 , showed a drop in OD for M-BGG from 0.91 to 0.14 af ter 3 years of chemotherapy and a drop from OD 0.56 to 0.28 for $M$. leprae and 1.08 to 0.21 for PG-I. The bacterial index in the same patient dropped from $3 \cdot 2$ to $2 \cdot 0$. Table 3 shows data from both JCT 1a and lc from a 3-year period of treatment. At the end of 3 years of chemotherapy, the antibody levels as detected by M-BGG had declined by $68 \%$, PG-I by $64 \%$ and $M$. leprae by $56 \%$ there was no significant difference found between JCT $1 \mathrm{a}$ and $1 \mathrm{c}$ in terms of decline of antibody levels to the leprosy antigens. Our ELISA did reveal more antibody decline with M-BGG and PG-I than with $M$. leprae.

COMPARISON OF DECLINES IN SPECIFIC ANTIBODY AND BACTERIAL INDEX DURING THE COURSE OF TREATMENT

Table 4 compares the decline of antibody levels as detected by M-BGG and the decline in bacterial 
Table 3. Percent decline in antibody levels with JCT la, $1 \mathrm{c}$ treatment regimens as measured by $\mathrm{M}-\mathrm{BGG}, \mathrm{PG}-1$ and $M$. leprae ELISA*

\begin{tabular}{|c|c|c|c|}
\hline Antigen & $\begin{array}{c}1 \mathrm{yr} \\
(n=22)\end{array}$ & $\begin{array}{c}2 \mathrm{yr} \\
(n=19)\end{array}$ & $\begin{array}{c}3 \mathrm{yr} \\
(n=19)\end{array}$ \\
\hline M-BGG & $\begin{array}{l}45 \%(21- \\
84) \dagger\end{array}$ & $56 \%(17-90)$ & $68 \%(48-94)$ \\
\hline PG-1 & $42 \%(9-82)$ & $55 \%(15-88)$ & $64 \%(2-95)$ \\
\hline M. leprae & $38 \%(5-72)$ & $51 \%(2-86)$ & $56 \%(5-81)$ \\
\hline $\begin{array}{r}* \text { JCT } \\
\text { da } \\
\text { rif } \\
\text { JCT } \\
\text { JCT } \\
\text { for } 24 \text { wee } \\
\dagger \text { Mea }\end{array}$ & $\begin{array}{l}\text { la regimen: } \\
\text { psone, } 100 \mathrm{mg} \\
\text { ampicin, } 1 \cdot 2 \mathrm{~g} \\
\text { 1c regimen: } \\
\text { la and clofazin } \\
\text { ks. }\end{array}$ & $\begin{array}{l}\text { six times per we } \\
\text { once on admis } \\
\text { nine, } 100 \mathrm{mg} 3 \\
\text { ange). }\end{array}$ & $\begin{array}{l}\text { ek for } 5 \text { years; } \\
\text { sion. } \\
\text { times per week }\end{array}$ \\
\hline
\end{tabular}

Table 4. Effect of treatment on lepromatous patients as measured by decline in ELISA antibody and Bacterial Index (BI)*

\begin{tabular}{lcccc}
\hline & \multicolumn{4}{c}{ Years of treatment } \\
\cline { 2 - 5 } & $\begin{array}{c}0 \\
(n=21)\end{array}$ & $\begin{array}{c}1 \\
(n=17)\end{array}$ & $\begin{array}{c}2 \\
(n=18)\end{array}$ & $\begin{array}{c}3 \\
\end{array}$ \\
& $100 \pm$ & $55 \pm 15)$ \\
\hline ELISA $\dagger$ & $100 \ddagger$ & $44 \pm 13$ & $32 \pm 12$ \\
BI & $4 \cdot 7 \pm 0 \cdot 4 \S$ & $3 \cdot 9 \pm 1 \cdot 0$ & $2 \cdot 9 \pm 1 \cdot 3$ & $2 \cdot 1 \pm 1 \cdot 0$ \\
\hline
\end{tabular}

* Chemotherapy was conducted at the Leonard Wood Foundation facility in Cebu, Philippines, in conjunction with the Sasakawa Memorial Health Foundation.

$\dagger$ M-BGG-ELISA anti-IgG am conjugate.

$\ddagger$ Percent of ELISA at start of treatment.

$\S \mathrm{SD}$.

index with 3 years of chemotherapy. The antibody levels can be seen to decline $68 \%$ of starting levels and the bacterial index, was found to decline from $4 \cdot 7$ to $2 \cdot 1$ over the 3 -year period.

\section{COMPARISON OF ELISA VALUES AND IMMUNOGLOBULIN LEVELS}

Table 5 presents a comparison of ELISA values and immunoglobulin levels over the course of 3 years of treatment of lepromatous patients. The mean levels of $\operatorname{IgG}$ and $\operatorname{IgM}$ declined with treatment, but remained elevated above the mean of normal sera. The IgG had an initial value of $2716 \pm 552,2506 \pm 704$ after 1 year of therapy, $2484 \pm 822$ after 2 years and $2244 \pm 804$ after 3 years. The IgM before treatment was $259 \pm 72$ and declined to $214 \pm 65$ after 1 year, to $207 \pm 68$ after 2 years and to $195 \pm 68$ after 3 years of therapy. Although declining slightly, the IgG levels remained far above normal values which indicates that there was chronic hypergammaglobulinanemia maintained in the face of treatment. The levels of $\operatorname{IgM}$ had moved close to the upper limits of normal 
Table 5. Comparison of immunoglobulin levels and ELISA activity over the course of treatment of lepromatous patients

\begin{tabular}{|c|c|c|c|c|c|}
\hline & \multicolumn{4}{|c|}{ Years of treatment } & \multirow[b]{2}{*}{ Normal values } \\
\hline & $\begin{array}{c}0 \\
(n=21)\end{array}$ & $\begin{array}{c}1 \\
(n=17)\end{array}$ & $\begin{array}{c}2 \\
(n=18)\end{array}$ & $\begin{array}{c}3 \\
(n=15)\end{array}$ & \\
\hline $\operatorname{IgG}$ & $2716 \pm 552 \dagger$ & $2506 \pm 704$ & $2484 \pm 822$ & $2244 \pm 804$ & $1125(710-1540) \ddagger$ \\
\hline IgM & $259 \pm 72$ & $214 \pm 65$ & $207 \pm 68$ & $195 \pm 68$ & $121(37-204)$ \\
\hline $\operatorname{IgA}$ & $333 \pm 173$ & $417 \pm 208$ & $386 \pm 132$ & $492 \pm 177$ & $275(60-490)$ \\
\hline ELISA & $100 \S$ & $55 \pm 19$ & $44 \pm 13$ & $32 \pm 12$ & 0 \\
\hline \multicolumn{6}{|c|}{$\begin{array}{l}\text { * Chemotherapy was conducted at the Leonard Wood Foundation facility in } \\
\text { Cebu, Philippines, in conjunction with the Sasakawa Memorial Health Foundation. } \\
\dagger \text { Means SD. } \\
\ddagger \text { Means (Range). } \\
\S \text { Percent of initial ELISA reading. }\end{array}$} \\
\hline
\end{tabular}

ranges by the end of the 1st year of treatment and remained at these levels during the 3-year period. The other immunoglobulin, $\operatorname{IgA}$, was found to increase in value over treatment, but remained near the upper limits of normal, thus reflecting no significant change to or from abnormal values. We found that throughout the course of this study the majority of the serum samples collected from patients continued to maintain abnormally elevated levels of $\operatorname{IgG}(69 \%$ of 81 sera) while $43 \%$ of the sera had elevated levels of IgM and only $23 \%$ of the sera had elevated levels of IgA. The ELISA values by the end of 3 years had declined by $68 \%$. The ELISA conjugate used was anti-IgGAM and thus was reactive to all 3 major immunoglobulins.

\section{Discussion}

Regardless of the 2 protocols (1a \& 1c) used for treatment, we found antibody levels in lepromatous sera to both semisynthetic and natural antigens declined with length of treatment. The measurement of declining antibody titers in relation to treatment have been reported by others ${ }^{12,13,14}$ using different antigens and assays systems. Our report is important because it studies the effects of treatment on antibody levels to both natural and synthetic antigens of $M$. leprae over an extended period of time and compares the specific decline in antibody to $M$. leprae antigens with Bacterial Index and with serum immunoglobulin levels. A significant decline was demonstrable after 1 year of therapy and continued over time (Figure 1 and Table 3). By the end of the 1st year of therapy, antibody levels to the semisynthetic or neoglycoprotein antigen M-BGG had declined to a mean value $55 \%$ and median value of $58 \%$ of the initial ELISA values. By the end of the 2 nd year the median ELISA values had dropped to $39 \%$ of the initial values with a mean of $44 \%$. At the end of 3 years the median had reached $32 \%$ of the starting values with the mean also at $32 \%$. This is a decline of $68 \%$ over the 3 -year period af ter the initiation of therapy. We found that the decline in antibody levels as detected by ELISA correlated well with decline in the bacterial index and such declines continued with length of treatment. Two patients numbers 045 and 035 listed in Table 1, show an increase in BI after 2 years of treatment. Examination of their clinical records of these patients and the remaining patients show continued improvement during this period. Others ${ }^{15}$ have reported similar correlations between antibodies and bacterial index. Of the 3 antigens studied in Table 3, the greatest decline in ELISA reactivity with 3 years of treatment was seen with M-BGG (68\%) and PG-I (66\%). The reactivity to whole cell antigen $M$. leprae declined more slowly (56\%) during the 
same period. This may have been due to the complexity of the whole cell antigen: presentation of more epitopes and the use of an ELISA conjugate which measures $\operatorname{IgG}, \operatorname{IgM}$ and $\operatorname{IgA}$ reactivity.

We also examined these patients' sera for quantitative changes in IgG, IgM and IgA antibodies by radial immunodiffusion. There was no correlation between antibody levels and chemotherapy or ELISA values. Within a particular patient there were episodes of abnormally high levels of antibodies interspersed with normal values. Also, a particular patient could have abnormally high values of one class of antibodies and normal values for others. Touw ${ }^{16}$ also reported elevated immunoglobulins but no correlation with bacillary load or other clinical parameters. While the MBGG ELISA shows a $68 \%$ decline after 3 years of chemotherapy, many of the immunoglobulin levels remain above normal values. Thus, it is unlikely that the decline in ELISA values is merely the result of decline in immunoglobulin levels. We speculate that multidrug therapy, because its improved bacteriocidal activity, may generate a more rapid decline since the long term regimens examined herein were primarily monotherapy with dapsone. We are currently examining this unsubstantiated hypothesis on the effects of multidrug therapy and antibody specific antibody levels to $M$. leprae.

In summary, we found that in lepromatous patients followed over a period of more than 3 years antibody titers to $M$. leprae antigens declined throughout the duration of treatment. This decline in specific antibody also parallels the decline in Bacterial Index (BI). This decline in specific antibody was observed with 3 antigens: both M-BGG and PG-I specific antigens as well as with whole $M$. leprae. Significant decline $(>40 \%)$ was demonstrable after 1 year and decline continued with treatment such that by the end of 3 years of treatment antibody levels had declined by $>60 \%$ of original levels. In spite of the dramatic decline in antibody against $M$. leprae antigens, no correlation could be established within the patterns of class specific hypergammaglobulinanemia observed during the course of treatment. This assay could be useful for monitoring drug therapy and the emergence of drug-resistant bacilli in response to therapy. In spite of the dramatic decline in antibody against $M$. leprae antigens, no correlation could be established within the patterns of class specific hypergammaglobulinanemia observed during the course of treatment. It has been noted ${ }^{17}$ that nonviable mycobacterial 'skeletons' can persist well into therapy and present a chronic antigenic stimulus to the host.

\section{Acknowledgments}

This research was supported by the Leonard Wood Memorial American Leprosy Foundation, Rockville, Maryland; National Institutes of Allergy and Infectious Diseases Grant (AI 24154), the Pacific Health Research Institute, Honolulu, Hawaii; the Heiser Program for Research in Leprosy, New York, New York; the Sasakawa Memorial Health Foundation, Tokyo, Japan; and the University of Hawaii Office of Research Administration. We thank the Leonard Wood Memorial Staff in Cebu, PI and the Philippine Government, Department of Health for JCT data and sera. In addition, we thank Dr Li Futian of the Shanghai Zun Yi Hospital for his assistance with statistical methods.

\section{References}

1 Jacobson RR. In: Hastings (ed.), Leprosy, 1985, 193-222.

2 Melsom R, Harboe M, Naafs B. Class specific anti-Mycobacterium leprae antibody assay in lepromatous leprosy (BL-LL) patients during the first two to four years of DDS treatment. Int J Le pr, 1982; 50: 271 -81.

3 Sinha S, Sengupta U, Ramu G, Ivanyi J. Serological survey of leprosy and control subjects by a monoclonal antibody-based immunoassay. Int $J$ Lepr, 1985; 53: 33-8.

${ }^{4}$ Chakinis C, Scollard, D, Nelson K, Smith T, Ryan S, Brown A, Umland E, Vithayasai V, Schauf V. Antibodies to Mycobacterium leprae detected by enzyme linked (ELISA) and radio (RIA) immunoassay: Comparison among families with leprosy patients. Acta Lepr, 1984; 95: 387-94. 
${ }^{5}$ Douglas JT, Naka SO, Lee JW. Development of a n ELISA for detection of antibody in leprosy. Int J Lepr, 1984; 52: 19-25.

6 Voller A, Bidwell D, Bartlett A. Enzyme linked immunosorbent assay, 371-95. In: Manuel of Clinica; Immunology, Rose, NR, Friedman H (eds). Washington, DC: American Society of Microbiology, 1980.

7 Cho SN, Yanagihara DL, Hunter SW, Gelber RH, Brennan PJ. Serological specificity of phenolic glycolipid I f rom Mycobacterium leprae and use in serodiagnosis of leprosy. Infection and Immunity, 1983; 41: 107783.

${ }^{8}$ Hunter WS, Brennan PJ. Further specific extracellular phenolic glycolipid antigens and a related diacyphthiocenol from Mycobacterium leprae. J Biol Chem, 1983; 258: 7556-62.

9 Chatterjee D, Douglas JT, Cho SN, Rea TH, Gelber R, Aspinall GO, Brennan PJ. Synthesis of neoglycoproteins containing the 3,6-di-O-methyl-B-D-glucopyranosyl epitope and their use in serodiagnosis of leprosy. Glycoconjugate $J, 1985 ; 2$ : 187-208.

10 Mancini G, Carbonara AO, Heremans JF. Immunochemical quantitation of antigens by single radial immunodiffusion. Immunochem, 1965; 1: 235-54.

11 CRC Handbook of Tables for Probability and Statistics, Beyer WH (ed.), 1966.

12 Abe M, Young DB, Douglas JT. Demonstration of FLA-ABS and ELISA tests. In: Proc. of the Workshop on Serological Tests for Detecting Subclinical Infection in Leprosy. Tokyo: Sasakawa Memorial Health Foundation, 1983, 91-2.

13 Melsom R, Naafs B, Harboe M, Closs O. Antibody activity against Mycobacterium leprae antigen 7 during the first year of DDS treatment in lepromatous (BL-LL) leprosy. Lepr Rev, 1978; 49: 17-29.

14 Yoder L, Naafs B, Harboe M, B june G. Antibody activity against Mycobacterium leprae antigen 7 in leprosy: Studies on variation in antibody content throughout the spectrum and on the effect of DDS treatment and relapse in BT leprosy. Lepr Rev, 1979; 50: 113-21.

15 Schwerer B, Meeker H, Levis W. IgM antibodies against phenolic glycolipid I from Mycobacterium leprae in leprosy sera: relationship to bacterial index and erythema nodosum leprosum. Acta Le pr, 1984; 95: 395402.

16 Touw J, Langendijk E, Stoner G, Belechu A. Humoral immunity in leprosy: Immunoglobulin G and M antibody responses to Mycobacterium leprae in relation to various disease patterns. Inf Immun, 1982; 36: 885-92.

17 Miller R, Harnisch J, Buchanan T. Antibodies to mycobacterial arabinomannan in leprosy: correlation with reactional states and variation during treatment. Int J Lepr, 1984; 52: 133-9.

\section{TEACHING MATERIALS AND SERVICES}

\section{Supplies of thalidomide from Brasil}

In a previous issue of this journal, full details were given of the resumption of production and supply of thalidomide by Chemie Grunenthal in West Germany (Volume 58, Number 3, September 1987). We have also previously published sources for this drug in Brasil and we have recently received a letter from another company, in Sao Paulo, which offers this drug for sale. It is: Tortuga Companhia Zootécnica Agrária, Av. Brigadeiro Faria Lima, 1.409-14 ${ }^{\circ}$ andar, Jardim Paulistano, 01451 - São Paulo - SP, BRASIL. Telex (011) $22270+$.

\section{Department of Education, University of Manchester, UK}

From the current descriptive brochure:

The Department of Education of the University of Manchester is virtually unique in that it is able to offer a range of courses studying education from childhood to adulthood, in all its phases, in a single Department. Awardbearing courses are offered at all levels from Certificate, Diploma and Master's Degree, to the Degree of Doctor of Philosophy. Short, non-award bearing courses can also be designed on request.

Facilities available include the John Rylands University Library, which houses over 3 million volumes, and two Departmental libraries, one of which contains the largest collection of its kind in Europe. Technical resources include a microcomputing unit and photographic laboratories. A cottage in the heart of the beautiful Lake District provides a base for outdoor pursuits for students interested in sailing and canoeing: one of the many facilities offered by the Centre for Physical Education.

The diversity of the Department's activities engenders a network of national and international contacts in the field of Education, including link arrangements with a number of overseas universities. Its 80 academic and research staff offer a wide range of experience and expertise across many areas from the initial and in-service training of teachers in the UK, to the training of village health care workers in the developing world. Students from 50 countries are currently studying in the Department. The English Language Unit, in the Centre for Adult and Higher Education, offers a range of courses in TEFL and TESOL.

All enquiries to Prof essor John D Turner, Head, Department of Education, University of Manchester, Manchester M13 9PL, England. 


\section{Robert Cochrane Fund for Leprosy}

The fund, in memory of the contribution of the great leprologist Robert Cochrane, is administered by the Royal Society of Tropical Medicine and Hygiene. It is to be used to finance up to 3 travel fellowships each year to a maximum value of $£ 1200$ each.

The intention is to enable leprosy workers to travel for practical training in field work, or in research, or to enable experienced leprologists to travel in order to provide practical clinical training in a developing country. There is no restriction on the country of origin or destination providing the above requirements are fulfilled

Application forms are available from the Society and must be received by the Society at least 6 months ahead of the proposed trip. All applications must be sponsored by a suitable representative of the applicant's employer or study centre, and agreed by the host organization. A 2 page report on the travel/study should be submitted to the Society within 1 month of the recipient's return. Apply: The Administrator, Royal Society of Tropical Medicine and Hygiene, Manson House, 26 Portland Place, London WIN 4EY.

\section{The Italian Society of Tropical Medicine}

The Italian Society of Tropical Medicine (SIMET), a nonprofit organization, is a scientific society founded in 1983 under the patronage of the Ministry of Foreign Affairs (more precisely the 'Direzione Generale per la Cooperazione allo Sviluppo') to promote initiatives on a national level for better knowledge and more information on social problems and public health in developing countries.

The Italian Society of Tropical Medicine has opened: 1, A resource centre provided with scientific, inf ormative and teaching equipment, made up of magazines, books, publications, slides, films, etc., a vailable for the interested public. 2, A magazine 'La Medicina Tropicale nella Cooperazione allo Sviluppo' which deals with aspects of health cooperation and is available by subscription or after registration to SIMET. 3, An inf ormative bulletin 'Cooperazione Sanitaria' contains summaries of the most recent news, from international magazines, on the health cooperation programmes and also important events such as conf erences, congresses, symposia and ref resher courses in scientific sub jects. 4 , A traveller servicef or all those who go to tropical countries. This service advises on preventative precautions against the most important tropical diseases. 5, An informative service for the doctors, general practitioners or specialists in other disciplines about health precautions for patients travelling to developing countries.

Moreover, the goal of this centre is to promote and spread the knowledge of tropical medicine in the development cooperation on a wide base, through the organization of congresses, round tables, symposia and conf erences on specific subjects.

Further information: SIMET, Società Italiana di Medicina Tropicale, Piazzale Ponte Milvio, 20-00191 Roma, Italy. Tel. 3963702

\section{Takemi Program for International Health}

The Takemi Program in International Health at the Harvard School of Public Health seeks applications for a limited number of fellowships for research and advanced training on critical issues of international health, especially those relating to developing countries. The program focuses primarily on mobilizing, allocating and managing scarce resources to improve health, and on creating sound strategies for disease control and health promotion. The program brings together graduates of advanced degree programs and mid-career professionals from around the world from diverse disciplines. Appointments begin on September for a ten-month period. For additional information contact: Prof Lincoln C Chen, Director, Takemi Program in International Health, Harvard School of Public Health, 665 Huntington Avenue, Boston, MA 02115, USA.

\section{Socio-economic emancipation and village autonomy, India}

The Secretary of the Society for Socio-Economic Emancipation and Village Autonomy, Manika - 822 126, District Palamau, Bihar, India, has written with following information:

'We have been active in this region since November 1982. I take this opportunity to inform you that to date we have trained around 350 tribal families in Tassar silk cocoon rearing, 100 young boys and girls in Tassar silk spinning and weaving. We have recently started a training centre in hog's hair processing and paint-brush making. Silk and paint-brush production has already started and we are looking for suitable markets for these products.'

\section{Development of voluntary organizations}

We are grateful for the following information from Dr V Periaswami in Anakapalle, India:

'In your editorial of Leprosy Review (Vol. 58, No. 2, June 1987 under the heading "Development of Voluntary Organizations" it is stated that the first "Leper Asylum" was established in Calcutta early in the nineteenth century followed by another in Varanasi. May I mention that during the life of Guru Arjan Singh $(15 \cdot 4 \cdot 1563$ to $30 \cdot 5 \cdot 1606)$ the 5th Guru in succession of Sikh Gurus, established a "Leper Colony" at Taran Taran in Amritsar District of the present Pan jab State, North India. I request that you kindly publish this information as a news item in your esteemed journal. (Ref: Nagpur Times, (Sunday spread) published in India, 26.8.84.) 